\title{
12. \\ TEATAR U SPLITU U DOBA \\ DESNIČINE MLADOSTI: \\ POLITIKA I KULTURA
}

\section{Bojan Đorđević}

UDK: 792(497.5 Split)(091)

Izvorni znanstveni članak

Sažetak: U radu se, prvenstveno na osnovu arhivske građe sačuvane u Arhivu Jugoslavije, u Fondu Ministarstva prosvete Kraljevine Jugoslavije, daje istorijat osnivanja Narodnog pozorišta za Dalmaciju u Splitu, kao i pregled njegovog delovanja do gašenja 1928. godine. Pristup ovom problemu nije teatrološki, i ne tiče se toliko repertoara i unutarnjih odnosa u samom pozorištu, koliko mesta pozorišta u kulturnom, pa i političkom životu tadašnjega Splita. Aspekt sa koga se daju uvidi jeste prevashodno kulturnoistorijski, jer sudbina Narodnog pozorišta za Dalmaciju, i svi prepori i sukobi oko njega, zorno svedoče o kulturnoj atmosferi u Splitu dvadesetih godina prošloga stoleća.

Ključne reči: Split, pozorište (kazalište), teatar, kultura, politika

I.

rpsko-hrvatski kulturni odnosi u Kraljevini Srba, Hrvata i Slovenaca (docnije Kraljevini Jugoslaviji) ne daju se na pravi način analizirati bez uvida u dokumenta koja dosad nisu bila predmet istraživanja, to jest u arhivsku građu koja je odavno dostupna, ali, nažalost, još uvek nepročitana. Kao da se zaboravlja davno izrečeno Flintovo upozorenje da se mora pribeći „racionalnoj interpretaciji, spoznavanju prave biti činjenica i suštinskih odnosa među njima“. ${ }^{1}$

Duhovni sadržaji koji danas određuju kolektivno kulturno biće srpskog i hrvatskog naroda izgrađivani su i tokom jednoipovekovne kulturne, pa i političke simbioze. Te veze, koje su imale svoje zastoje i padove, ali nikada nisu potpuno prekidane, podrazumevale su, Ojkenovom terminologijom iskazano, ${ }^{2}$ određene uslove, okruženje i kulturološku podlogu.

1 „(...) it is simply the meaning, the rational interpretation, the knowledge of the true nature and essential relations of the facts." Robert Flint, History of the Philosophy of History I, New York 1894., 108.

2 Rudolf Eucken, „Philosophie der Geschichte“, Systematische Philosophie (= Die Kultur der Gegenwart, I/VI, ur. Paul Hinneberg), Berlin - Leipzig 1907., 277. 
Tek zbir svih tih faktora (istorijskih, političkih, socijalnih, kulturoloških, a napose individualnih) može nam zorno predstaviti srpsku/hrvatsku (a počesto i srpsko-hrvatsku) baštinu koje bi sada mnogi da se odreknu u paradoksalnom retroaktivnom ispisivanju istorije.

Danas na individualnom, opštem, pa i na nacionalnom nivou, počesto dominira tzv. selektivno pamćenje. Ono se najčešće temelji na stereotipima, koji previđaju da su kultureme proizvod složenih, često međusobno (pa i u sebi samima) protivrečnih okolnosti. Primer takve selektivne, ideološki usmeravane memorije jeste i percipiranje pozorišne tradicije Splita. Ono je, takvim neistorijskim razlozima posredovano, zapravo ne samo netačno, već i u samome sebi kontradiktorno. Tako je tokom 2013. godine u hrvatskoj štampi na velika zvona oglašen jubilej splitskog pozorišta. Pisalo se o sto dvadeset godina moderne pozorišne tradicije u Splitu, iako je, zapravo, belodano jasno da podizanje pozorišne zgrade samo po sebi ne znači i početak teatra, već da teatar započinje rad osnivanjem ansambla, što se međutim te 1893. godine nije desilo. S druge strane, napis u Hrvatskoj enciklopediji (a nacionalna enciklopedija po definiciji treba da bude zbir istorijski proverenih, jasnih i čvrsto utemeljenih podataka) u potpunosti negira prethodnu tezu, pošto postojanje splitskog pozorišta pomera u osvit Drugog svetskog rata:

Hrvatsko narodno kazalište u Splitu osnovano je 1940. U sedam mjeseci djelovanja izvelo je 22 dramske, 2 operske i 1 baletnu premijeru, pod vodstvom I. Tijardovića, M. Foteza, O. Jozefovića i A. Roje. Drugi je put osnovano 1945, iz Kazališta narodnog oslobođenja Dalmacije, pod intendanturom I. Tijardovića. ${ }^{3}$

Sve ove proizvoljnosti i apsolutne netačnosti, naravno, nisu posledica neznanja, već nametanja selektivnog pamćenja posredovanog ideološkim razlozima, tj. potpunim odbacivanjem jednog dela kulturne tradicije Splita - njegovog pozorišnog života - između dva svetska rata. Jer, jedina prava, činjenično proverljiva istina govori da je Hrvatsko narodno kazalište u Splitu zvanično osnovano 17. septembra 1920. godine, a svečano otvoreno 17. oktobra 1921. godine, pod nazivom Narodno pozorište za Dalmaciju. Najbolji način da se to potvrdi, te da se izbegnu sve manipulacije, jeste okretanje primarnom informacionodokumentacionom materijalu - arhivskim izvorima.

\section{2.}

Jedan od prioritetnih zadataka koje je sebi postavilo Ministarstvo prosvete novostvorene jugoslovenske države bilo je podržavljenje već postojećih pozorišta, kao i osnivanje novih oblasnih pozorišta. Formalno su u vlasništvo nove države preneta pozorišta u Zagrebu, Beogradu, Ljubljani i Novom Sadu, ${ }^{4}$ a potom se pristupilo osnivanju oblasnih pozorišta u Skoplju, Sarajevu, Osijeku i Splitu. Prioritet je dat Splitu, prvenstveno zbog toga što je

3 Hrvatska enciklopedija, sv. 4: Ft-Ht (ur. August Kovačec), Zagreb 2002., 721.

4 Mere za podržavljenje ovih pozorišta sproveo je, po nalogu Umetničkog odeljenja Ministarstva prosvete Kraljevine Srba, Hrvata i Slovenaca, tadašnji upravnik beogradskog Narodnog pozorišta Milan Grol. Videti: Arhiv Jugoslavije (dalje: AJ), Fond Ministarstva prosvete Kraljevine Jugoslavije (66)-575-938 (6. 11. 1920.). 
imao pozorišnu zgradu, a potom i tradiciju koja je sezala tridesetak godina unazad (naravno, imala se u vidu i renesansna prošlost grada), i bila oličena u gostovanjima raznih dramskih i operskih trupa. ${ }^{5} \mathrm{Ne}$ treba, zatim, zaboraviti da je vreme neposredno posle ujedinjenja bilo doba teških iskušenja s obzirom na italijanske pretenzije na Dalmaciju. Pokretanje domaćeg pozorišta shvaćeno je kao najbolje sredstvo za odbranu prava Kraljevine SHS na dalmatinsku obalu, te kao način za suzbijanje propagande tamošnjih Italijana. Zato je već u septembru 1919. godine u Dalmaciju upućen profesor Dragutin Kostić, kao specijalni izaslanik Ministarstva prosvete Kraljevine SHS. Posle detaljnog uvida u postojeće stanje, on je iz Dubrovnika, 21. septembra 1919. godine, Ministarstvu prosvete uputio Izveštaj o radu na organizaciji oblasnog pozorista u Splitu. ${ }^{6}$

Kostić se sastao sa predsednikom splitske opštine Ivom Tartagliom, ali i sa mnogim drugim uglednim Splićanima, poput predsednika pozorišne uprave advokata Rikarda Baja, zatim knjižara i vlasnika bioskopa te pozorišnog blagajnika Josipa Karamana, slikara Emanuela Vidovića, osnivača i urednika Novog doba Vinka Kisića, profesora, filologa i književnika Josipa Barača. Želja Splićana da, konačno, dobiju stalno profesionalno pozorište sa sopstvenim glumačkim ansamblom i repertoarom nije bila upitna, posebno imajući u vidu činjenicu koju Kostić naročito ističe, „da je Split podigao sebi pozorišni dom još početkom osamdesetih godina prošlog stoleća“ i da „kad je početkom devedesetih godina izgorela prva zgrada, Splićani su podigli drugu, mnogo veću, na Bulatovoj poljani, god. 1893.“. Za tu zgradu Kostić veli da je „veća i prostranija od beogradskog Narodnog pozorišta“?

Kostić, zatim, ističe ljubav Splićana prema umetnosti, posebno pesmi i igri, navodeći da u gradu deluje pet pevačkih društava, Gradski orkestar i Splitska filharmonija. ${ }^{8}$ Potom Kostić zalazi u detalje vezane za osnivanje pozorišta, te ističe da mu je Tartaglia garantovao subvenciju splitske opštine, kao i ostalih gradova i varoši u kojima bi splitsko pozorište po dužnosti gostovalo (tu je pre svega imao u vidu Trogir, Šibenik, Dubrovnik i Kotor). Međutim, već tada je pokrenuto pitanje opere, koje će ostati neuralgična tačka prepora i jedan od katalizatora kriza koje su splitski teatar pratile od osnivanja. I Kostić je bio svestan finansijskih problema vezanih za utemeljivanje opere: „Zbog mnogo većih režijskih i dr. troškova za operu, našli smo da bi trebalo državnu subvenciju za pozorište u Splitu povećati bar još za polovinu predviđene sume od 100.000 kruna, naročito za početak koji mora da bude što bolji.“9 Ipak, iz izveštaja se vidi da su predstavnici grada naročito insistirali na operi.

Drugo pitanje o kojem se Kostić izjašnjava jeste pitanje uprave pozorišta. Kostić i Tartaglia saglasili su se u tom trenutku da bi za upravnika najbolje rešenje bio kompozitor i

5 O pozorišnom životu u Splitu od podizanja pozorišne zgrade 1893. godine do svršetka Prvog svetskog rata videti: Nevenka BezIĆ-BožAnić, „Novinske vijesti o scenskim priredbama u Splitu (1884-1918)“, Dani hvarskog kazališta, sv. 7: Moderna, Split 1980., 397-454. Period o kome se govori u našem radu tek je ovlaš i u kratkim crtama naznačen u spomenici posvećenoj splitskom Hrvatskom narodnom kazalištu. Videti: Ivo Batistić, „Splitsko kazalište između dva rata“, Narodno kazalište Split 1893-1953., Split 1953., 21-33.

6 Izveštaj videti u: AJ 66-608-1001.

7 Isto.

8 „Split je i u pogledu drugih umetnosti, naročito slikovnih, jedan od prvih u Kraljevstvu našem po umetničkom obrazovanju svojih građana (odgajio je pored Meštrovića, Vidovića, Rosandića, Foretića, Ćipika, i veći broj mladih umetnika)."Isto. 
dirigent Dragutin Pokorni, nekadašnji šef orkestra Narodnog pozorišta u Beogradu i kapelnik Orkestra Srpske kraljevske garde. Predviđeno je da mu zamenik bude Josip Hatze, kompozitor i u to vreme horovođa splitskog pevačkog društva "Gusar". Pored njih, u pozorištu bi, za početak, bili stalno zaposleni (pored glumaca) još samo dekorater (scenograf) i blagajnik (sekretar).

Posle ovoga izveštaja, inicijativu je preuzeo Ivo Tartaglia kao predsednik opštine. Najpre se 16. decembra 1919. godine obratio pismom Zemaljskoj vladi, ističući poguban uticaj italijanskih pozorišnih družina kao najvažniji razlog za osnivanje nacionalnog pozorišta. ${ }^{10}$ Ipak, Tartaglia je bio svestan da bi opera u tom trenutku bila veliki zalogaj, i s obzirom na finansije, ali i s obzirom na to da bi nju gledala „samo predratna publika, sa finim svojim ukusom“, što ne bi bilo isplativo. ${ }^{11}$ Tartaglia je, pak, insistirao na utilitarnoj funkciji pozorišta, koje bi imalo tu ulogu da privuče sebi širu publiku i podigne kulturni i duhovni nivo splitskih građana. Za to je, po njegovom mišljenju, najbolja drama, „jer se toj novoj publici, skoro laiku u književnosti i umjetnosti, mora pružiti mogućnost odgoja koji joj je potreban". ${ }^{12}$

Potom je 14. januara 1920. godine Tartaglia uputio pismo načelniku Umetničkog odeljenja Ministarstva prosvete. ${ }^{13}$ Sreća je bila - i, videće se, veoma povoljna okolnost za razvoj splitskog pozorišta - što se na tom odgovornom položaju tada nalazio slavni srpski komediograf Branislav Nušić. Ko bi bolje od njega, inače nekadašnjeg upravnika Narodnog pozorišta u Beogradu, razumeo probleme sa kojim se suočavalo jedno pozorište u osnivanju? $\mathrm{Na}$ to je Tartaglia računao kada je Nušiću skrenuo pažnju na dva ključna problema. Prvi je pitanje upravnika. Tartaglia je, uprkos poštovanju koje je imao za Pokornog, ipak bio mišljenja „da upravitelj bude osoba ukusa i velike spreme e da uzmogne zadovoljavati velikim zahtjevima“. ${ }^{14}$ Opšta želja u Splitu bila je da upravnik budućeg pozorišta bude poznati glumac Ivo Raić, koji „uživa kod nas glas priznatog umjetnika, ne samo kao glumac, nego i kao stvaratelj“.15

Drugo važno pitanje bilo je šta učiniti sa ložama koje su bile vlasništvo pojedinaca, i čiji vlasnici nisu bili voljni da ih ustupe. ${ }^{16}$ Tartaglia je predložio da se ovaj problem reši po ugledu na milansku Skalu, tako što će grad od vlasnikâ zakupiti lože na devet godina, a da bi vlasnici koji sami žele da zakupe sopstvene lože bili oslobođeni plaćanja ulaznica.

10 Pismo videti u: AJ 66-608-1001.

11 Tartaglia je smatrao da se pre osnivanja opere mora osposobiti dovoljno muzički obrazovanih ljudi u samome Splitu, pa je kao „hitnu potrebu“" predložio osnivanje državne muzičke škole. Isto.

12 Isto. Ta podvojenost između omiljenih operskih i operetskih predstava s jedne, i dramskog repertoara s druge strane, bila je obeležje pozorišnog života u Splitu između dva svetska rata: „Osvjedočena omiljenost opere i operete održava kazališni kontinuitet..., iako je glazbena i izvedbena dojmljivost tih žanrova već od polovice 19. stoljeća u suprotnosti s idejom o nacionalno dominantnoj ulozi dramskog stvaralaštva.“ Antonija Bogner-ŠABAN, „Splitsko kazališno društvo“, Dani hvarskog kazališta, sv. 29: Hrvatska književnost i kazalište dvadesetih godina 20. stoljeća, Zagreb - Split 2003., 192.

13 Pismo videti u: AJ 66-608-1001.

14 Isto.

15 Isto.

16 Iz jednog članka u tadašnjoj štampi vidi se da su vlasnici loža optuživali Gradsko veće da smera da po svaku cenu osnuje pozorište, iako ono „ne bi pružilo prvorazrednu igru“. Život, 2/1920., br. 221, 3. 
Nušić je ozbiljno shvatio Tartaglino pismo. Ipak, zbog obaveza nije mogao lično da ode u Split, kako mu je predlagao Tartaglia. No, poslao je svog specijalnog izaslanika, sekretara Ministarstva prosvete, poznatog srpskog pesnika Simu Pandurovića.

\section{3 .}

Sima Pandurović je u to vreme već imao višegodišnju prosvetnu karijeru, koju je otpočeo 1907. godine kao mladi suplent Nepotpune muške gimnazije u Valjevu, ${ }^{17}$ gde je predavao srpski jezik, nemački jezik i geografiju. ${ }^{18} \mathrm{Uz}$ to je radio i kao honorarni nastavnik nemačkog jezika u Privatnoj višoj ženskoj školi u Valjevu. ${ }^{19}$ Godine 1911. prešao je u novoosnovanu Srpsku kraljevsku četvrtu mušku gimnaziju u Beogradu, gde je predavao srpski jezik. ${ }^{20} \mathrm{Od}$ novembra 1913. godine bio je pisar Ministarstva prosvete Kraljevine Srbije. Za vreme Prvog svetskog rata ostao je u okupiranom Beogradu, gde je životario u oskudnim uslovima. Zahvaljujući Milanu Ogrizoviću jedno vreme radio je kao vaspitač u Domu za nezbrinutu decu u Kragujevcu. ${ }^{21}$ Ipak, ni to ga nije sasvim zaštitilo, kao ni činjenica da mu je Društvo hrvatskih književnika u Zagrebu izdalo zbirku izabranih pesama Okovani slogovi, ${ }^{22}$ pa je pred kraj rata interniran u logor u Nežideru. ${ }^{23}$ Po povratku iz logora, ${ }^{24}$ jedno vreme bio je i dalje bez posla, a potom je ponovo postavljen za pisara Ministarstva prosvete Kraljevine SHS. Nezadovoljan zbog lošeg položaja i male plate, uputio je dopis Ministarstvu prosvete žaleći se na tretman i zahtevajući povišicu plate i unapređenje: „Nužno je pomenuti da sam poslednjih godina, za vreme okupacije, upropašćen od strane neprijatelja materijalno i zdravstveno; da sam zbog svoga ispravnoga držanja bio gonjen, zatvaran i interniran, i da ni s pogledom na to prema meni nije bilo obzira ni od strane neprijatelja, ni od strane moga naroda i moje države. “25 Pandurovićeva molba je urodila plodom, i on je postavljen za sekretara Ministarstva prosvete.

U tom svojstvu Pandurović je, prema „usmenom naređenju“ načelnika Umetničkog odeljenja Ministarstva prosvete Branislava Nušića, otišao početkom 1920. godine u Split,

17 Kraljev ukaz o postavljenju Sime Pandurovića za suplenta Nepotpune muške gimnazije u Valjevu videti u: Arhiv Srbije (dalje: AS), Fond Ministarstva prosvete Kraljevine (dalje: MPs), f. 47, r. 82. Podelu časova videti u: AS, MPs, f. 36, r. 148 (20. 9. 1907.).

18 Videti: Državni kalendar Kraljevine Srbije za godinu 1908., 66; Državni kalendar Kraljevine Srbije za godinu 1909., 67; Državni kalendar Kraljevine Srbije za godinu 1910., 67.

19 Videti: Državni kalendar Kraljevine Srbije za godinu 1908., 74; Državni kalendar Kraljevine Srbije za godinu 1909., 75; Državni kalendar Kraljevine Srbije za godinu 1910., 78.

20 Videti: Istorijski arhiv Beograda, Fond Četvrte muške gimnazije, 4.1.278, Upisnica za školsku 1911/12. godinu; Upisnica za školsku 1912/13. godinu. Takođe i: Državni kalendar Kraljevine Srbije za godinu 1911., 69; Državni kalendar Kraljevine Srbije za godinu 1912., 66. O radu Sime Pandurovića u ovoj gimnaziji videti: Bojan ĐorĐević, Koordinate: Srpska kraljevska četurta gimnazija 1910./11. - Gimnazija „Sveti Sava“2010.-11., Beograd 2011., 16-17. AS, Vojni generalni guverneman (VGG), VIII-1465.

22 Videti vest o tome u: Beogradske novine (Beograd), br. 286, 22. 10. 1918., 2.

23 „Poznati pesnik Sima Pandurović doteran je ovih dana u Boldogasonj, u mošonskoj županiji, gde je sada interniran." Velika Srbija (Solun), br. 884, 26. 9. 1918., 2.

24 „Iz Nežidera je doputovao naš poznati književnik, gosp. Sima Pandurović, u povoljnom zdravlju.“ Večernje novosti (Beograd), br. 13, 6. 11. 1918., 2.

25 AJ 66-401-649 (28. 8. 1919.). 


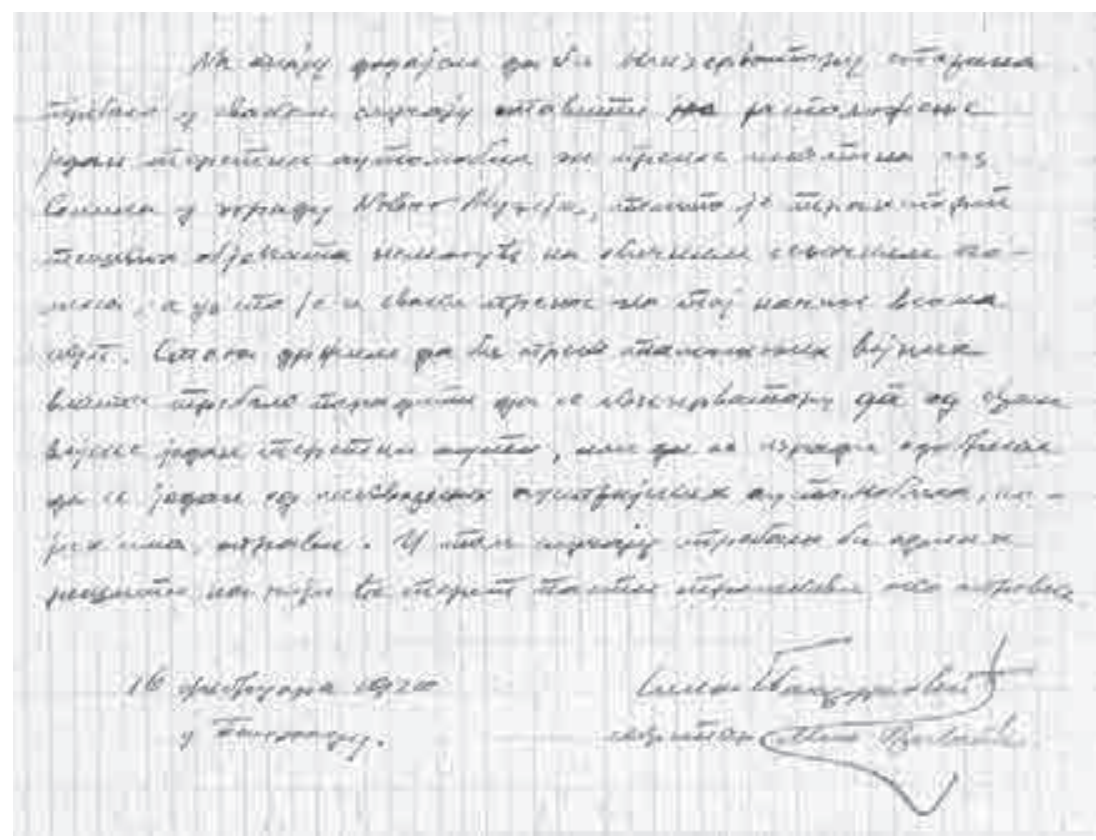

Sl. 1. Završni dio Referata o pozorišnim i kulturnim prilikama u Splitu Sime Pandurovića

i po povratku, 16. februara 1920. godine, podneo Nušiću Referat o pozorišnim i kulturnim prilikama u Splitu. ${ }^{26}$ Ni Pandurović nije propustio priliku da u uvodu svoga referata iskaže mišljenje da je u tom trenutku Split grad od najveće strateške važnosti za novostvorenu jugoslovensku državu:

Nalazeći se, u geografskom pogledu, na tački koja je od eminentne političke, kulturne i nacionalne važnosti, sa kulturom i spomenicima iz daleke prošlosti, Split zaslužuje svaku moguću pažnju s naše strane. Ako se ne zaboravi da je i Split, pored ostale dalmatinske obale, bio stalna težnja italijanskih aspiracija, da je prirodno i neminovno bio na dometu italijanske kulturne ekspanzije, i da je, pored svega, zadržao i razvio svoje nacionalno kulturno osećanje - onda potreba naglašena u pređašnjoj alineji postaje još očiglednijom. $\mathrm{Na}$ svaki način, dakle, da je posle političkog ujedinjenja Jugoslavije, najvažnije stabiliziranje i razvijanje kulturnog života u celoj zemlji, a pogotovu na Primorju i centrima Dalmacije. ${ }^{27}$

Pandurović, potom, prelazi na detalje sporazuma koji je on, po Nušićevom ovlašćenju, utanačio sa gradskim čelnicima Splita, i za koji se nadao da će i od strane Ministarstva prosvete „biti i definitivno utvrđen i legalizovan“. Po prvoj tački tog sporazuma, splitsko oblasno pozorište bilo bi isključivo dramsko, jer za operu nije u tom trenutku bilo ni dovoljno kvalitetnog pevačkog kadra, ni dovoljno novca. Osim toga, „razlozi zdravog umetničkog razvitka, razlozi čuvanja od talijanskih i stranih uticaja, razlozi politički i nacionalni, govore takođe za dramu“. ${ }^{28}$

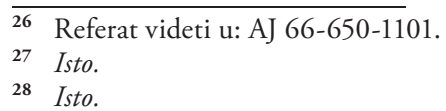


Druga tačka sporazuma ticala se problema sa vlasnicima loža. Pandurović i Tartaglia dogovorili su se da Ministarstvu prosvete predlože tri moguća rešenja, s obzirom na to da pozorište bez gledalaca u ložama, sa parterom od samo 250 sedišta, ne bi bilo profitabilno. Prvi modus bio bi da država od vlasnikâ otkupi lože. Drugi je da vlasnici kaparišu predstave, tj. da mogu da koriste lože najviše za trideset predstava godišnje, a da za ostale predstave mesta u ložama budu u slobodnoj prodaji. Najzad, prema trećem predlogu, sopstvenici loža bi se dobrovoljno odrekli svoga prava „s obzirom na opšti interes i dužnosti u novom vremenu“, i to pravo preneli na pozorišnu upravu. Naravno, u tom slučaju dotadašnji vlasnici loža imali bi pravo preče kupovine karata za sve predstave. Iz docnije odluke Ministarstva prosvete vidi se da je opštinska uprava Splita uspela da ubedi vlasnike loža da se priklone ovoj trećoj varijanti. Za to su najviše zasluga imali Mihajlo Marković i predsednik Pokrajinske vlade Ivo Krstelj, koji su prvi ustupili upravi svoje lože. ${ }^{29}$

Treća tačka sporazuma, najzad, odnosila se na izbor budućeg upravnika pozorišta. Uprkos želji splitskih vlasti i uglednih građana, koju je prethodno u svom pismu formulisao Tartaglia, Ministarstvo prosvete nije bilo sklono da se složi sa tim da Ivo Raić bude upravnik, prevashodno zbog toga što nije imao iskustva u rukovođenju ovakvom institucijom. Pandurović je gradskim čelnicima preneo nameru Ministarstva prosvete da za upravnika postavi književnika Nika Bartulovića i za to dobio njihovu načelnu saglasnost, o čemu je obavestio Nušića: „Građanstvo bi vrlo dobro primilo postavljanje g. Nika Bartulovića za upravnika. “30 Ovome je Pandurović dodao svoj predlog da Ivo Raić ipak bude angažovan u splitskom teatru, kao „artistički direktor“. To se, međutim, nikad nije dogodilo.

Ovaj preliminarni dogovor formalizovan je 17. septembra 1920. godine, kada je u Split došao zamenik načelnika Umetničkog odeljenja Ministarstva prosvete, srpski dramaturg i prevodilac Milan Dimović. On je u potpunosti uvažio zahteve splitske gradske uprave i predložio da se odmah imenuje upravnik, a da pozorište bude svečano otvoreno u julu ili avgustu sledeće godine. ${ }^{31}$ Već sutradan, 18. septembra 1920. godine, Niko Bartulović je imenovan od strane Ministarstva prosvete Kraljevine SHS za upravnika Narodnog pozorišta za Dalmaciju, kako je glasio zvaničan naziv splitskog pozorišta. Bartulović je na dužnost stupio tek tri meseca docnije, 17. decembra 1920. godine, jer je pre toga morao da posvršava svoje profesionalne i lične poslove u Zagrebu. On je primio imovinu ugašenog Kazališnog diletantskog društva, koja je pripala novoosnovanom pozorištu. Tada je imenovao i scenografa. Bio je to Radovan Tommaseo, profesor splitske Umetničke obrtne škole. ${ }^{32}$ Zamolio je, takođe, da iz Zagreba bude doveden i Mihajlo Marković. ${ }^{33}$ Ministarstvo prosvete je 31. decembra 1920. godine potvrdilo sve Bartulovićeve odluke i premestilo Mihajla Markovića u Split, s tim da mu Bartulović „po svom nahođenju odredi koju

29 AJ 66-608-1001 (29. 9. 1920.). Inače, za slučaj da dogovor sa vlasnicima loža izostane, Pandurović je predlagao da se tada jednostavno izvrši eksproprijacija loža!

30 AJ 66-650-1101.

31 AJ 66-608-1001.

32 O ugledu ove škole, iz koje je potekao čitav niz istaknutih splitskih slikara, videti: Ante SAPUNAR - Dora SAPUNAR, „Slikar Mate Meneghello otrgnut zaboravu“, Kulturna baština, 38/2012., 189-190.

33 Mihajlo Marković je još 1907. godine u Splitu osnovao privatnu pozorišnu družinu koja je predstave davala širom Dalmacije i Istre. Videti: N. BEZıć-BožAnıć, „Novinske vijesti o scenskim priredbama u Splitu“, 401. 
hoće dužnost“ ${ }^{34}$ Iz ovoga se vidi koliko je vlastima bilo stalo da što pre počne sa radom Narodno pozorište za Dalmaciju.

Pozorište u Splitu najzad je svečano otvoreno 17. oktobra 1921. godine. ${ }^{35} \mathrm{Na}$ otvaranju su besedili načelnik Umetničkog odeljenja Ministarstva prosvete Branislav Nušić i predsednik splitske opštine Ivo Tartaglia. Posle toga, izvedena je premijera drame Jugana, vila najmlada Mirka Korolije, a odmah potom, u Nušićevu čast, i njegova drama Knez Ivo od Semberije. ${ }^{36}$ Kako svedoči jedan izveštač, „svečanost je imala, pored opšteg kulturno-umetničkog, u sadašnjem trenutku pretežno nacionalno-politički značaj, jer je tesno vezana za ideju duhovnog jedinstva“. U Splitu se, tako, „spontano manifestovala ideja jedinstva i radost oslobođenja “. ${ }^{37} \mathrm{Ta}$ ideja jedinstva rukovodiće dalji rad Nika Bartulovića kao upravnika Narodnog pozorišta za Dalmaciju, sasvim u skladu sa ideologijom Orjune, u kojoj je Bartulović isticao kulturni rad na „pobijanju pojava, koje u sebi kriju bilo plemenski, verski ili klasni separatizam"..$^{38}$ To izraženo jugoslovenstvo, koje će, međutim, s vremenom poprimiti dogmatični vid i biti uzdignuto na ravan ideologije, $s$ jedne strane će činiti da splitsko pozorište prevaziđe regionalne okvire, ali će, s druge, biti i katalizator stalnih kriza koje će, pored drugih razloga, dovesti i do njegovoga gašenja.

Jesen 1921. godine bila je veoma uspešna za splitsko Narodno pozorište za Dalmaciju. Nekoliko premijera bilo je vrlo posećeno i kritički pozitivno propraćeno. To je dalo povoda Ivu Tartagli da u svojstvu predsednika opštine još jednom obavesti Ministarstvo prosvete o zadovoljstvu Splićana svojim pozorištem, ali i da zatraži povećanje državne subvencije:

Iz brzojavne zahvale što ju je opštinska uprava ovog grada prigodom otvorenja Narodnog pozorišta odaslala gospodinu Ministru prosvjete, mogao je gospodin Ministar najbolje da se uvjeri, kakovim je željama ovaj grad dočekao podignuće tog kulturnog hrama, a gospodin načelnik Umjetničkog odeljenja je i vidio oduševljenje čitavog građanstva prigodom svečanog otvorenja. Ministarstvo prosvete sigurno vrlo dobro pozna kulturne tradicije u Dalmaciji i Splitu, a da bi trebalo to opetovati, i samo ćemo naglasiti, da je, na udaru tuđinštine, pozorište u Splitu (koje gostuje i u Šibeniku i Dubrovniku) nadasve važno i sa nacionalno-političke strane, kao možda nijedno drugo pozorište u državi. Spomenuti ćemo kao primjer samo nedavnu sjajnu predstavu u počast američke flote, sa koje su i admiral Niblack i svi oficiri ponijeli najljepše utiske, a to svakako i za naš prestiž pred stranim svijetom nešto znači. ${ }^{39}$

\footnotetext{
34 Sva ova dokumenta videti u: AJ 66-608-1001.

35 AJ 66-575-938.

36 Videti: „Splitska svečanost“, Politika (Beograd), br. 4845, 19. 10. 1921., 2.

37 S. Milijanović, „U Splitu i Sarajevu“, Politika (Beograd), br. 4863, 7. 11. 1921., 2-3. Zanimljiva je vest koja se pojavila u izveštaju dopisnika slovenskog lista Slovenski narod, a koja govori da je uprava splitskog pozorišta imala nameru da pokrene pozorišni list: „List bo službeno glasilo splitskega gledališča in bo prinašal slike umetnikov in umetnic z zanimivo vsebino." Slovenski narod (Ljubljana), br. 234, 16. 10. 1921., 3.

38 Niko Bartulović, Od revolucionarne omladine do Orjune, Split 1925., 83.

39 AJ 66-575-938 (6. 1. 1922.).
} 
Pošto je određeno da državna subvencija za splitsko Narodno pozorište bude samo 250000 dinara, oglasilo se pismom Ministarstvu finansija Općinsko upraviteljstvo, navodeći da su potrebe mnogo veće: „Već se pri osnivanju Narodnog pozorišta za Dalmaciju u Splitu upozoravalo na vrlo težak položaj tog Pozorišta, a to radi velikih zahtjeva, koji će se na Pozorište postavljati... “40 Ispostavilo se, naime, da postoje tri razloga koja govore u prilog povećanju subvencije. Uprkos prvobitnoj rezervi, odlučeno je da Narodno pozorište za Dalmaciju ima i svoju operu, što je povećalo troškove, ali je, kako se u dopisu kaže, povećalo i posetu. Drugi razlog je što se ispostavilo da uređenje zgrade i nabavka tehničke opreme koštaju više nego što je pretpostavljano. Najzad, doneta je i odluka o prijemu stalnog dramaturga, pa se i za to mora izdvojiti novac: „Usljed svega toga, počelo se Pozorište boriti sa financijalnim neprilikama i palo je u dug. Kada bi se nastavilo dosadanjim putem, splitsko bi se Pozorište nužno moralo da raspadne. ${ }^{“ 41} \mathrm{Na}$ ovo je ministar finansija pozitivno odgovorio i povećao subvenciju na 500000 dinara, „s obzirom na poznatu mi zadaću tamošnjeg pozorišta“" ${ }^{42} \mathrm{U}$ jesen 1922. godine subvencija je još povećana i iznosila je 600000 dinara, ${ }^{43}$ ali je i tako splitsko pozorište primalo najmanje novca od svih pozorišta u Kraljevini SHS. ${ }^{44}$ Takvo stanje nije se moglo popraviti povremenim dobrotvornim predstavama i svečanostima, ${ }^{45}$ i pozorište je bilo primorano da pravi dugove. ${ }^{46}$ Nešto novca prikupljeno je tokom 1923. i 1924. godine zahvaljujući dobrotvornim priredbama u korist splitskog pozorišta, kao i dobrovoljnim prilozima. Treba istaći da se među imenima onih koji su priložili značajnije sume novca nalaze i imena većine tzv. splitskih kročeanaca, kao i ime Uroša Desnice. ${ }^{47}$ Ipak, veoma značajan je jedan dopis direktora gimnazije u Šibeniku, Marka Ježine, od 17. maja 1924. godine. U tom opsežnom dopisu, zapravo izveštaju o radu u prethodnoj školskoj godini, upućenom Odeljenju za srednju nastavu Ministarstva prosvete Kraljevine SHS, Ježina šalje spisak učenika šibenske gimnazije koji su u školskoj 1923/24. godini učestvovali u organizaciji raznih priredbi i proslava i koji su zbog toga predloženi za ,javnu pohvalu“. U tom spisku stoji i sledeća odrednica: „Desnica Vladan, maturant - organizovao sa velikim uspjehom korisnicu u svrhu prikupljanja novca za Narodno pozorište za Dalmaciju. “48

Pitanje dramaturga, pak, rešeno je tek maja 1924. godine. Istina, honorarno je taj posao obavljao Mirko Korolija još od samog osnivanja pozorišta, ali je to bilo skopčano sa veli-

\footnotetext{
40 AJ 66-356-594 (12.5. 1922.).

41 AJ 66-356-594.

42 AJ 66-356-594 (11. 7. 1922.).

43 AJ 66-356-594 (13. 10. 1922.).

44 Prema finansijskom izveštaju s kraja 1922. godine, Narodno pozorište u Beogradu primalo je subvenciju od 8.996.100 dinara, Hrvatsko narodno kazalište u Zagrebu 7.374.000, pozorište u Ljubljani 4.281.992, u Skoplju 1.200.000, u Novom Sadu 1.000.000, u Osijeku i Sarajevu po 750.000, a u Splitu 600.000 dinara. Izveštaj videti u: AJ 66-575938 (28. 12. 1922.).

45 Videti: Anatolij KudRJAvcev, „Igre i svečanosti u splitskom kazalištu između dva svjetska rata“, Dani hvarskoga kazališta, sv. 31: Igra i svečanost u hrvatskoj književnosti i kazalištu, Zagreb - Split 2005., 313-320.

46 Ti dugovi su dospevali na naplatu još i 1932. i 1933. godine, dakle posle fuzije sa pozorištem u Sarajevu. Dugovalo se glumcima, rediteljima, zaposlenima, splitskoj opštini. Državno pravobranilaštvo u Splitu je krajem 1933. godine obavestilo Ministarstvo prosvete da splitsko pozorište (koje pravno nije više postojalo) ima dugove prema čak pedeset šest osoba ili pravnih lica! AJ 66-575-939 (12. 12. 1933.).

47 AJ 66-575-939.

48 AJ 66-913-1317 (17. 5. 1924.).
} 
kim problemima i troškovima. Naime, Korolija je bio sekretar Ministarstva prosvete, te je, da bi radio dramaturške poslove za splitsko Narodno pozorište, često uzimao odsustva. ${ }^{49}$ Zbog toga je polovinom 1923. godine zatražio da bude penzionisan, ne bi li se više posvetio radu u splitskom pozorištu. ${ }^{50}$ Bartulović je, međutim, početkom 1924. godine naišao na blagonaklon stav tadašnjeg ministra prosvete Svetozara Pribićevića i načelnika Umetničkog odeljenja Ministarstva prosvete Riste Odavića, i poslao dopis u kome je naglasio:

Posvjedočavam, da je Dr. Mirko Korolija od osnutka ovog pozorišta, t.j. od juna 1921. do danas vršio dužnost dramaturga ovog pozorišta savjesno i marljivo, te na zadovoljstvo uprave, i da je, prema svemu tome, najpodesniji da popuni budžetom predviđeno mjesto ukaznog dramaturga kod ovog pozorišta. ${ }^{51}$

Konačno, kraljevim ukazom od 7. maja 1924. godine Mirko Korolija imenovan je za dramaturga Narodnog pozorišta za Dalmaciju u Splitu, kao činovnik prve kategorije šeste grupe. ${ }^{52}$ Tada se Korolija preselio u Split.

Međutim, tek što je to pitanje rešeno, došlo je do kulminacije krize u samom pozorištu, ali i problema u odnosu pozorišta prema drugim kulturnim institucijama u Splitu. Ta zategnutost počela je još u leto 1923. godine, kada je pozorište bilo gotovo pred prestankom rada, i kada je lično upravnik Niko Bartulović morao da ode u Beograd i pred ministrom obrazlaže stav koji je, docnije, izneo i u pismu, to jest „da treba spasiti, ne samo dramu, nego svakako i operu, i to iz razloga kulturnih i nacionalnih, a i praktičnih, jer bi, makar i privremenim rasturanjem opere, propale i druge dve gradske ustanove, splitska Filharmonija i Nar. glazba“. ${ }^{33}$ Ovaj problem je rešen privremeno, tako što je opštinska uprava spasla operu dajući Narodnom pozorištu kredit. ${ }^{54}$ Godinu dana docnije, sa dolaskom Mirka Korolije za stalnog dramaturga, i Bartulović je - sigurno i pod Korolijinim uticajem - stao na stanovište da sve snage iz kuće, kao i sve finansije, treba usmeriti na Dramu, te da Operu više nije moguće održati. Tome se protivila Filharmonija, ali i deo opštinske uprave. ${ }^{55} \mathrm{Zbog}$ toga je Niko Bartulović krajem jula 1924. godine podneo ostavku na mesto upravnika. ${ }^{56}$ Opštinska uprava ostavku nije prihvatila. Za zamenika upravnika imenovala je Vladimira Jakšu, a zaključila je da se Bartulović mora „na lijep način navesti da ostavku povuče“.57 Usledila je, međutim, odlučna akcija Mirka Korolije. Ne treba smetnuti s uma, naime, da je on dugo godina radio u Ministarstvu prosvete i tamo stekao veliki ugled. Zbog toga je lično ministru prosvete poslao poverljivo pismo u kome je, bez ikakve zadrške, detaljno opi-

\footnotetext{
49 Videti dopis upravnika Nika Bartulovića upućen Ministarstvu prosvete u: AJ 66-356-594 (4. 5. 1923.).

50 Korolija je penzionisan 22. jula 1923. godine. Videti: AJ 66-356-594. Vest o njegovom penzionisanju objavljena je i u tadašnjoj beogradskoj štampi. Videti: Pravda (Beograd), br. 200, 25. 7. 1923., 3.

51 AJ 66-356-594 (15. 4. 1924.).

52 AJ 66-356-594.

53 AJ 66-609-1001 (2.9. 1923.).

54 O teškoj krizi splitskog pozorišta izveštavao je i dopisnik beogradskog lista Vreme iz Splita. Videti npr.: „Agonija splitskog pozorišta“, Vreme (Beograd), br. 608, 30. 8. 1923., 6.

55 Detaljan opis ovog spora pružio je načelnik Školskog odeljenja Splitske oblasti u svom pismu ministru prosvete. Videti: AJ 66-609-1001 (8. 8. 1924.).

56 AJ 66-609-1001 (27. 7. 1924.).

57 AJ 66-609-1001 (30. 7. 1924.).
} 
sao sve mahinacije koje su se događale u pozorištu i u samom gradu. ${ }^{58}$ Skrenuo je ministru pažnju na „skrivene ciljeve i mahinacije“ dela splitskog građanstva i Filharmonije. Naime, Filharmonija je zapala u velike dugove i pretila je opasnost od njenog gašenja. Zbog toga je Vladimir Jakša, inače član uprave Filharmonije, i poveo ovu zakulisnu akciju, s ciljem da postane upravnik Narodnog pozorišta. Zanimljivo je da iz Korolijinog dopisa saznajemo da je Jakša bio bivši policijski komesar! Njihovu logiku Korolija svodi na reči jednog od članova uprave Filharmonije: „Neka ima Filharmonija, a Pozorištu kako bude.“ Zbog toga je Korolija zatražio direktnu intervenciju ministra prosvete, predloživši definitivno ukidanje Opere, jer je Drama ,jezgra i raison d'être ovog Pozorišta“. Korolija je pristao da i dalje vodi Dramu samo pod uslovom da ni dinar subvencije ne ide za Operu. Zamolio je ministra da utiče na Bartulovića da povuče ostavku. Na kraju je uveravao ministra da predsednik opštine Ivo Tartaglia potpuno podržava pozorišnu upravu i da je „užasnut“ postupcima dela građanstva. ${ }^{59}$

Korolijino pismo je, sigurno, bilo presudno da ministar prosvete ne uvaži Bartulovićevu ostavku, te da poveća subvenciju Narodnom pozorištu za Dalmaciju. Međutim, pažljivo pristupajući ovom problemu, ministar prosvete nije pristao da Opera bude ukinuta, nego je ovoga puta Ministarstvo prosvete uzelo kredit za Operu. ${ }^{60}$

Šta se u međuvremenu desilo i je li došlo do otopljavanja na relaciji pozorište - grad filharmonija, ne može se dokumentovati. Ali, činjenica je da već u jesen te, 1924. godine, upravnik Niko Bartulović zahvaljuje ministru na pomoći, a posebno na tome što je dao sredstva za Operu, tvrdeći sada „da je u Splitu opera apsolutno nužna, i da treba sve učiniti da je se čim prije uskrsi““. ${ }^{61}$ Jer, u međuvremenu, članovi Opere, u neizvesnosti hoće li ona opstati, u većini su otišli u druga pozorišta, pre svega u Sarajevo, Zagreb i Beograd. Bartulović je tražio od ministra da oni budu dekretom vraćeni u Split. ${ }^{62}$ Ipak, sezona 1924/25. počela je bez Opere.

Ubrzo potom, 6. novembra 1924. godine, u Narodnom pozorištu za Dalmaciju priređena je velika svečanost povodom četrdeset godina rada Branislava Nušića. ${ }^{63}$ Okupili su se svi viđeni Splićani, a Nušiću je odato posebno priznanje „za zasluge u utemeljivanju našega kazališta" ${ }^{64}$ Ipak, to nije moglo da prikrije probleme koji su se javljali pred upravom Narodnog pozorišta za Dalmaciju. Nekoliko nedelja posle Nušićeve proslave Niko Bartulović se

58 Istini za volju, još krajem 1922. godine grupa glumaca Narodnog pozorišta za Dalmaciju uputila je Centralnoj upravi Udruženja glumaca Kraljevine SHS pismo u kome se naglašavalo da se „već otpočetka osjeća odbojnost stanovitih splitskih krugova, a sad već i otvoreno neprijateljstvo“. AJ 66-360-602. Videti i: A. KudrJavcev, „Igre i svečanosti u splitskom kazalištu“, 316.

Korolijino poverljivo pismo videti u: AJ 66-609-1001 (10. 8. 1924.).

60 AJ 66-609-1001 (21. 8. 1924.). I beogradska štampa izvestila je o tome da je Niko Bartulović povukao ostavku i da je „red u splitskom pozorištu ponovo uspostavljen“. Videti: „Rešenje krize splitskog pozorišta“, Vreme (Beograd), br. 971, 2. 9. 1924., 5.

AJ 66-609-1001.

63 Koliko se sada zna, prva predstava neke Nušićeve komedije izvedena je na splitskoj pozornici 1907. godine. Izvelo ju je Kazališno diletantsko društvo, a radilo se o komediji Put oko sveta. N. BEzıĆ-BožAnić, „Novinske vijesti o scenskim priredbama u Splitu“, 414.

64 AJ 66-609-1001. 


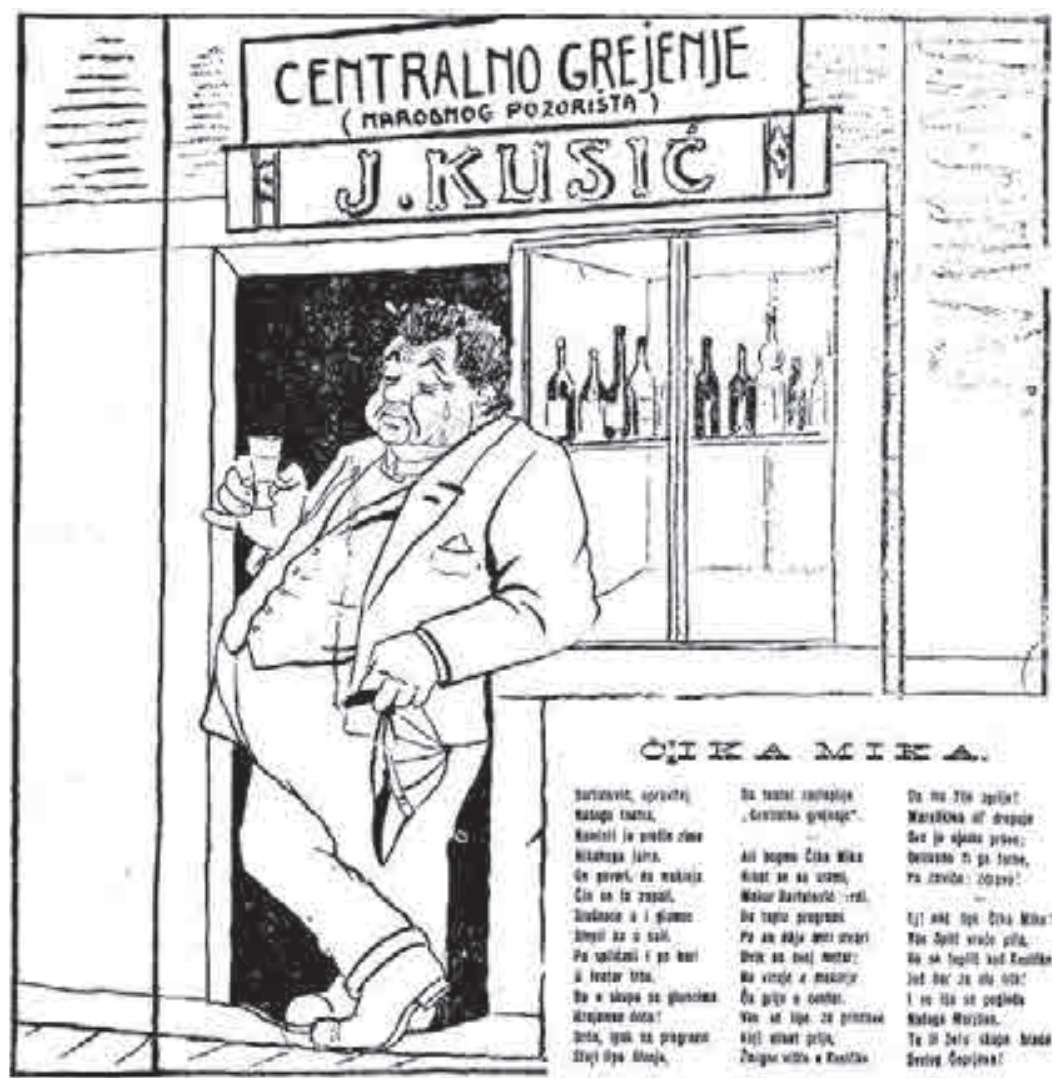

Sl. 2. Splitsko kazalište na udaru kritike Duje Balavca 1923. godine

ponovo žalio ministru prosvete Svetozaru Pribićeviću da pozorište ima vrlo male prihode od predstava u Splitu. Tako su od početka sezone izvedene samo dve premijere - Bibliotekar i Nora, a Mrtva straža je otkazana, jer je prodato samo šest ulaznica! Ispostavilo se, naime, da Narodno pozorište za Dalmaciju bolju posetu ima na gostovanjima u Šibeniku, Dubrovniku i Trebinju: „Moje je mišljenje, da je glavni uzrok tome neraspoloženju publike prema pozorištu u ukidanju opere, koju je publika teško pregorela. “65 Dakle, ponovo se kao najteži ukazao problem nedostatka Opere. Bartulović je, međutim, ovim svojim pismom detektovao i političko i ideološko stanje u Splitu toga vremena. Požalio se na „pojave separatizma“, ukazujući na harangu lista Hrvatska riječ protiv Narodnog pozorišta za Dalmaciju i njegove uprave. List je pozivao na bojkot i tvrdio da je nedopustivo što su „u upravi Pozorišta sami Jugoslaveni, koji angažiraju samo Srbe, a proganjaju Hrvate“. List je za Bartulovića, Koroliju, ali i samoga Tartagliu tvrdio da su „sluge režima“. Posledica toga, veli Bartulović, bila je i osnivanje Malog kazališta kao „separatno hrvatskog“. ${ }^{66}$ Bartulović

\footnotetext{
$\overline{65}$ AJ 66-575-938 (23. 11. 1924.).

66 I u novije vreme se ističe da splitsko pozorište nije imalo onaj ugled u narodu upravo zbog svoje unitarističke i jugoslovenske politike: „Kazališna uprava je bila podložna utjecajnoj sferi centralističkih sila, kojima se stari hrvatski izričaj nije uklapao u ideološki projekat jedinstvenog jugoslavenskog naroda i jezika.“ Ivan BošKović, „Odjeci čina ujedinjenja 1918. godine u dramskoj književnosti i kazalištu“, Croatica et Slavica Iadertina, 3/2007., 307.
} 
je, ipak, istakao da „većina inteligencije u Splitu - a ta najviše posjećuje pozorište - ipak nije politički orijentirana kao 'Hrvatska riječ'“ ${ }^{67}$ Međutim, iz pisma se vidi da se Bartulović umorio od stalne borbe za opstanak pozorišta, i stoga je svoje pismo završio eksplicitnim pozivom Pribićeviću: „Ili pozorište zatvoriti, ili mu jednom radikalnom akcijom pomoći.“68 Radikalna akcija je, međutim, ponovo izostala, i dugovi su trenutno sanirani tako što je Ministarstvo prosvete Narodnom pozorištu za Dalmaciju dalo dodatnu subvenciju od milion dinara i odobrilo kredit od pola miliona dinara. ${ }^{69}$

Sledeće dve godine, 1925. i 1926, bile su period nešto mirnijeg bitisanja i rada Narodnog pozorišta za Dalmaciju. Arhivska dokumenta svedoče o redovnim aktivnostima, subvencijama i novim premijerama. Vrhunac rada Narodnog pozorišta za Dalmaciju bilo je gostovanje u Beogradu oktobra 1925. godine. Za dve nedelje splitsko pozorište izvelo je šest predstava, a gostovanje je bilo propraćeno i u štampi. Najviše uspeha imala je Bartulovićeva Bijedna Mara rađena prema Botićevom delu. Najavljujući ovo gostovanje, Niko Bartulović je u intervjuu listu Vreme izložio istorijat splitskog pozorišta, okolnosti koje su dovele do njegovog osnivanja, istakao zasluge srpskih književnika i samoga Ministarstva prosvete, ali nije okolišao kada je trebalo govoriti o problemima. I ovde je, ponovo, ukazao da se oko splitskog pozorišta vode zakulisne igre koje zadiru u njegov ,jugoslavenski karakter“. Bartulović je bio dosledno i decidirano angažovan na liniji jugoslovenskog jedinstva, i u ovom intervjuu ponovo je nagovestio da se on neće povinovati zahtevima „opskurnih separatističkih kreatura" ${ }^{* 70}$

Ipak, Bartulović, najzad, nije izdržao pritiske. Godine 1926. dao je konačnu ostavku, a na mestu upravnika Narodnog pozorišta za Dalmaciju nasledio ga je dotadašnji dramaturg i direktor Drame, književnik Mirko Korolija. ${ }^{71}$ I on je imao da se suočava sa stalnom nestašicom novca, rastućim sepatratizmom, nezadovoljstvom glumaca i osipanjem publike. U pismu Ministarstvu prosvete početkom 1927. godine priznao je da su glumci i zaposleni, prvi put od osnivanja, dva meseca ostali bez plate. ${ }^{72}$ Uprava je zbog toga bila prinuđena da 1. marta 1927. godine svima da otkaz, i da i zvanično (iako je praktično već dugo nije bilo) likvidira Operu i Operetu. Uz to je i hor, kako je Korolija pisao, „otkazao poslušnost“ ${ }^{\text {"73 }}$ Ministarstvo prosvete reagovalo je tako što je ponovo odobrilo kredit Narodnom pozorištu za Dalmaciju i ono je nastavilo da radi, ali u znatno smanjenom obimu. Glumci i zaposleni su 1. aprila 1927. godine ponovo potpisali ugovore, ali je sada spisak zaposlenih redukovan na dvadeset jednog glumca (među njima bili su i tada mladi, a docnije slavni glumci Blaženka Katalinić, Fran Novaković, Salko Repak i Viktor Starčić), jednog šaptača, jednog inspicijenta, blagajnika, sekretara (bio je to glumac i docnije poznati reditelj Jovan Jeremić), tzv. voditelja kancelarije, ekonoma i upravnika. Opera je i definitivno bila ugašena. Tako

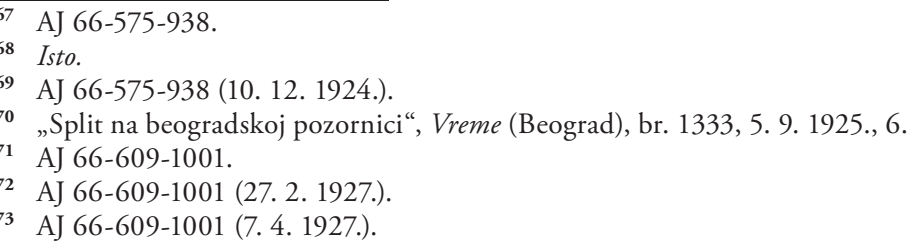


je Narodno pozorište za Dalmaciju, koje je otpočelo sa devedeset osam zaposlenih, spalo na broj od dvadeset osam! ${ }^{74}$

Istog dana kada je iz splitskog pozorišta otposlan ovaj akt Ministarstvu prosvete, u suprotnom pravcu poslat je akt koji je i za Mirka Koroliju, i za Iva Tartagliu, i za sve članove ansambla i zaposlene, predstavljao hladan tuš. Predložena je fuzija splitskog i sarajevskog pozorišta u Narodno pozorište za zapadne oblasti, s tim da sedište bude u Sarajevu. ${ }^{75}$ Splitska opština oštro je odgovorila, ponavljajući sve one razloge za opstanak pozorišta koje su i Tartaglia, i Dragutin Kostić, i Sima Pandurović navodili kada je to pozorište osnivano. ${ }^{76}$ Međutim, šteta je već načinjena. Poslednja predstava u Narodnom pozorištu za Dalmaciju održana je 27. decembra 1927. godine. ${ }^{77}$ Svestan gotovo tragične situacije, Ivo Tartaglia je u poslednjem, očajničkom pismu Ministarstvu prosvete zapretio da će splitska opština oduzeti pozorištu zgradu ukoliko se u njoj ne budu redovno održavale predstave! ${ }^{78}$ Bio je to poslednji pokušaj da se spasi što se spasti može. Kao što je poznato, spasa nije bilo. Odlukom Ministarstva prosvete Kraljevine SHS izvršena je fuzija sarajevskog i splitskog pozorišta. ${ }^{79}$ Ona je, međutim, izvedena tako da je splitsko pozorište bilo naprosto pripojeno sarajevskom, ${ }^{80}$ i faktički prestalo da postoji 1. aprila 1928. godine. ${ }^{81}$ Time je završena relativno kratka, ali burna, devetogodišnja epizoda u razvoju teatra u Splitu. Teatra kome su utemeljivači i osnivači bili Srbi i Hrvati jugoslovenske provenijencije. Zaborav koji je na to pao, i sa srpske i sa hrvatske strane, predstavlja ogrešenje o nepobitne činjenice, i znatno osiromašuje kulturnu istoriju grada Splita.

\footnotetext{
Videti: AJ 66-609-1001 (15. 6. 1927.).

AJ 66-609-1001 (15. 6. 1927.).

AJ 66-609-1001 (30. 6. 1927.).

AJ 66-356-594.

78 AJ 66-609-1001 (15. 2. 1928.).

79 AJ 66-609-1001 (1. 4. 1928.).

80 Detaljan prikaz ovoga fuzionisanja videti u: Josip Lešıć, „Spajanje sarajevskog i splitskog pozorišta“, Sarajevsko pozorište izmedu dva rata (1918-1929). Zbornik radova, Sarajevo 1976., 260-305.

81 Nije prošlo dugo, i već se pokazalo koliko je štetno bilo ovo fuzionisanje, pre svega po kulturni život u Splitu. Stoga je Kraljevska banska uprava Primorske banovine 3. februara 1930. godine uputila pismo ministru prosvete, tražeći da se obnovi rad Narodnog pozorišta za Dalmaciju, pošto spajanje sa sarajevskim pozorištem nije uspelo zbog „kulturnih i psiholoških razlika“. Kao razlozi za ponovno otvaranje splitskog pozorišta navedene su nekolike činjenice, koje se u suštini nisu razlikovale od onih iznošenih 1919. i 1920. godine, prillikom zasnivanja Narodnog pozorišta za Dalmaciju. Najpre, da je Split „jako vjekovno središte Primorja i čitave Primorske banovine, oko kojega su se uvijek okupljali svi kulturni, nacionalni, privredni i socijalni elementi iz prirodne nužde, da se na Jadranu okupe intelektualne i osjećajne snage našeg naroda, za uspješno vođenje borbe proti prisezanju i penetraciji tuđinske misli i vlasti“. Potom, da je „pred djelovanjem pozorišta u Splitu počela (...) sve više popuštati kulturna i politička premoć domaćih izrođenih i talijanskih elemenata“. Međutim, otkad je pozorište ugašeno, „italijansko društvo u Splitu 'Gabinetto di lettura' hoće da pokrene svoje kazalište, što će biti od vrlo teških posljedica i sa državnog gledišta“. AJ 66-356-594.
} 


\section{$\cos$}

\section{Theatre in Split at the Time of Desnica's Youth: Politics and Culture}

One of the priority tasks undertaken by the Ministry of Education of the newly-formed Yugoslav state was bringing the already existing theatres under state management, as well as founding new, regional theatres. Priority was given to Split, primarily because it already had a theatre building, and also because it had a tradition of some thirty years in theatre, during which time various drama and opera companies performed in Split (and of course, the Renaissance heritage of the town was taken into account). Initiation of a domestic theatre was seen as the best means to defend the right of the Kingdom of Serbs, Croats and Slovenes to the Dalmatian coast, as well as a way to counter the propaganda by the local Italians. For that reason, the well-known Serbian comedy writer Branislav Nušić, the then head of the Arts Department of the Ministry of Education of the Kingdom of Serbs, Croats and Slovenes, ardently endorsed the opening of the theatre in Split. First Dragutin Kostić, and then the Serbian poet Sima Pandurović went to Split for that reason. They met with prominent Split intellectuals, headed by Mayor Ivo Tartaglia, and over time they managed to solve the most important questions that were the precondition for opening the theatre - the question of repertory, that is, of the relationship between Drama and Opera in the theatre; the question of theatre boxes, and the question of director. The National Theatre for Dalmatia was officially founded on 17 September 1920, and the Croatian writer Niko Bartulović was appointed Director. Over its entire duration the National Theatre for Dalmatia had to struggle with various challenges. One of them was the constant dissatisfaction of the Split citizenry over the inferior position of the Opera, which was discontinued for a period of time. The other problems were of ideological and political character. The circles around the journal Hrvatska riječ, which had a nationalist orientation, charged the Theatre with an alleged "Orjuna and Great-Serbian" essence, and with marginalization of Croatian actors and Croatian writers. Still, the most difficult problem was constant lack of funds, for which reason the Theatre often had to often contend with the fact that best actors and opera singers were leaving it. The situation did not improve considerably even when the writer Mirko Korolija, who was dramaturgist up to that point, became Director, and eventually the National Theatre for Dalmatia was fused with the Sarajevo Theatre, and de facto abolished, on 1 April 1928. The last performance was held much earlier, on 27 December 1927. That was the end of a relatively short but tumultuous nine-year episode in the development of theatre in Split, a theatre whose founders were prominent Serbs and Croats of a Yugoslav provenance.

Key words: Split, theatre, culture, politics

\section{$\cos$}

\section{Izvori}

Arhiv Jugoslavije, Ministarstvo prosvete Kraljevine Jugoslavije (66)

Arhiv Srbije, Ministarstvo prosvete Kraljevine Srbije (MPs)

Vojni generalni guverneman (VGG)

Istorijski arhiv Beograda, Fond Četvrte muške gimnazije (4.1.278) 
Beogradske novine (Beograd)

Novo doba (Split)

Politika (Beograd)

Pravda (Beograd)

Slovenski narod (Ljubljana)

Večernje novosti (Beograd)

Velika Srbija (Solun)

Vreme (Beograd)

Život (Split)

\section{Literatura}

Niko Bartulović, Od revolucionarne omladine do Orjune, Split 1925.

Ivo Batistić, „Splitsko kazalište između dva rata“, Narodno kazalište Split 1893-1953., Split 1953., 21-33.

Nevenka Bezić-BožAnić, „Novinske vijesti o scenskim priredbama u Splitu (1884-1918)“, Dani hvarskog kazališta, sv. 7: Moderna, Split 1980., 397-454.

Antonija Bogner-ŠABAn, „Splitsko kazališno društvo“, Dani hvarskog kazališta, sv. 29: Hrvatska književnost i kazalište dvadesetih godina 20. stoljeća, Zagreb - Split 2003., 192-230.

Ivan BošKović, „Odjeci čina ujedinjenja 1918. godine u dramskoj književnosti i kazalištu“, Croatica et Slavica Iadertina, 3/2007., 279-317.

Rudolf Eucken, „Philosophie der Geschichte“, Systematische Philosophie (= Die Kultur der Gegenwart, I/VI, ur. Paul Hinneberg), Berlin - Leipzig 1907.

Robert Fuint, History of the Philosophy of History I, New York 1894.

Anatolij KuDRJAVCEv, „Igre i svečanosti u splitskom kazalištu između dva svjetska rata“, Dani hvarskog kazališta, sv. 31: Igra i svečanost u hrvatskoj književnosti i kazalištu, Zagreb - Split 2005., 313-320.

Josip Lešrć, „Spajanje sarajevskog i splitskog pozorišta“, Sarajevsko pozorište izmedu dva rata (19181929). Zbornik radova, Sarajevo 1976., 260-305.

Ante Sapunar - Dora Sapunar, „Slikar Mate Meneghello otrgnut zaboravu“, Kulturna baština, 38/2012., 179-196. 